\title{
Does Flood Disaster Lessen GDP Growth? Evidence from Malaysia's Manufacturing and Agricultural Sectors
}

\author{
Mai Syaheera M. Shaaria \\ Mohd Zaini Abd Karim ${ }^{b}$ \\ Bakti Hasan-Basric \\ Universiti Utara Malaysia
}

\begin{abstract}
Flood disaster has incurred remarkable costs to human, social and economic aspects, affecting not only the local but national and world economy as well. Flood is the most significant natural hazard in Malaysia, particularly in terms of its frequency and duration, size of the affected areas and economic damages. This paper examines the impacts of flood disaster on gross domestic product (GDP) growth in the agricultural and manufacturing sectors in Malaysia for the period of 1960 to 2013 by applying the Autoregressive Distributed Lag (ARDL) bounds testing approach for cointegration and error correction model (ECM) for short-term relationship. Augmented Dickey-Fuller (ADF) test, Phillips-Perron (PP) test and Kwiatkowski-Phillips-Schmidt-Shin (KPSS) unit root test examines the stationarity of the series. Results show that the series are cointegrated. The findings suggest that size of affected areas affects agricultural growth in both the long run and short run. Meanwhile, total damage cost also appears to affect manufacturing growth in both the long run and short run. The results of the study have important implications on the country's agricultural and manufacturing sectors.
\end{abstract}

Keywords: Agricultural growth, flood disaster, GDP growth, manufacturing growth JEL classification: 010

\section{Introduction}

In general, Malaysia had experienced many occurrences of major floods since 1960 . There are 31 occurrences of flood for the period 1980-2010 resulting in human loss of 40 people with 20,624 people affected and USD60,242 million of economic damages on average every year. Figure 1 shows cases of serious floods in Malaysia for the period 1965-2010 in terms of damage cost and number of people affected. For example, floods that hit Kuala Lumpur and many other states in January 1971 resulted in the death of 61 people and a loss of more than USD37 million. In fact, Johor experienced massive floods due to abnormal heavy rainfall in the year 2006/2007. The total cost of these

a Othman Yeop Abdullah Graduate School of Business, Universiti Utara Malaysia, Sintok, 06010, Kedah, Malaysia. Email: s93684@student.uum.edu.my, mai.syaheera@yahoo.com

b Othman Yeop Abdullah Graduate School of Business, Universiti Utara Malaysia, Sintok, 06010, Kedah, Malaysia. Email: zaini500@uum.edu.my (Corresponding author)

c School of Economics, Finance and Banking, Universiti Utara Malaysia, Malaysia. Sintok, 06010, Kedah, Malaysia. Email: bakti@uum.edu.my

* The authors wish to thank the Ministry of Higher Education Malaysia for funding this study under the Long Term Research Grant Scheme (LRGS/b-u/2012/UUM/Teknologi Komunikasi dan Informasi). The views expressed in this study are those of the authors and do not necessarily reflect the views or policies of the ministry or the project team. Any errors are the sole responsibility of the authors. 


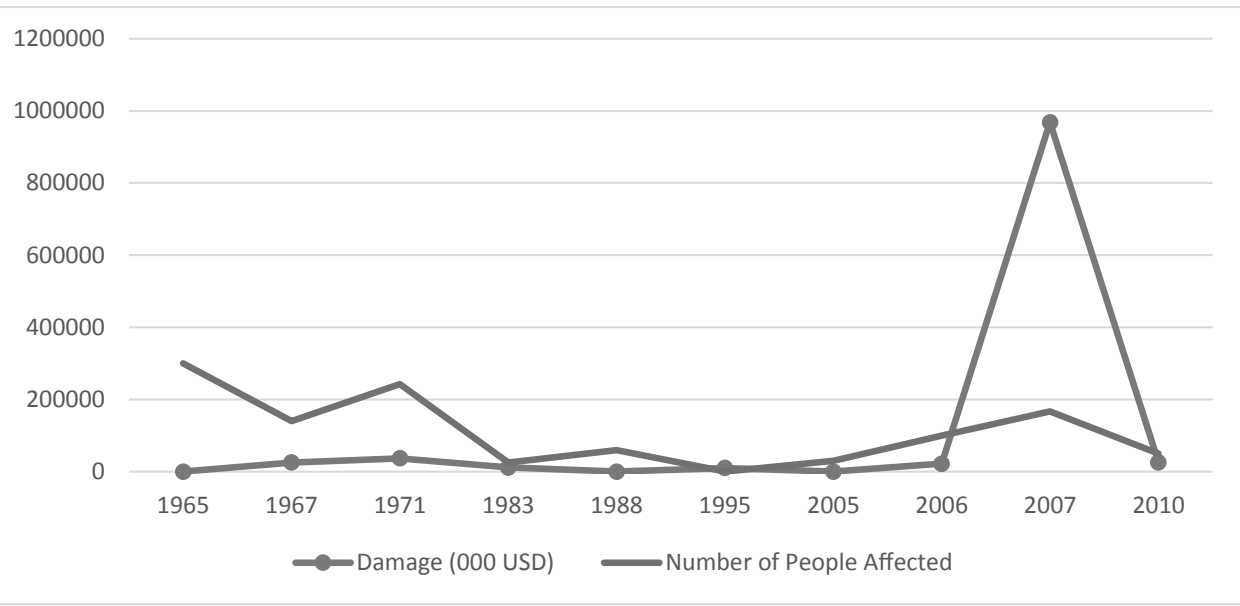

Figure 1. Number of people affected and damage costs in most serious cases of floods in Malaysia, 1965-2010

floods were estimated to be nearly USD1 billion. ${ }^{1}$ Furthermore, these occurrences were considered as the most costly flood events in Malaysian history. Whenever flood occurs, daily economic activities would be disrupted and will certainly have an adverse effect on the nation's economy. Although flooding is almost a yearly occurrence, its effect on Malaysia's economic growth is not known.

Post-flood recovery seems to be the major problem relating to the effects of flood occurrences in Malaysia. Among others, the demand for goods will surged back to pre-flood levels, while production continues to decline. There is a significant fall in production of goods, followed by a fall in GDP growth after the event. This situation forces every sector to increase prices of their readily available goods and services. Furthermore, during and after floods, the recovery process increases government spending. However, the impacts of flood disasters depend on the level of economic activities. For example, due to demand and supply shocks, shifting terms of trade and changes to production compositions caused by flood disasters lead to immediate negative growth shocks.

In addition, the impacts of flood disaster are intensified and may vary across sectors. These events typically appear to affect mainly the agricultural sector, followed by the fisheries and forestry sectors. Furthermore, because of a decrease in activities due to reduction in production capacities and disruption to transportation, the manufacturing sector may be affected as well. According to a study by Albala-Bertrand (1993), a delay in inputs such as water, energy, materials and direct effects on workers and their productivity will lead to a fall in production capacity. On the whole, flood disaster is a major potential threat affecting capital stock, productivity and in fact, a potential barrier to economic growth.

1 EM-DAT: The CRED International Disaster Database. 
Noorazuan (2006) found that approximately 10 percent of Malaysia's GDP is contributed by the agricultural sector for the period 2006-2010. At least one third of the country's population depends on the agricultural sector for their livelihood. Furthermore, the manufacturing sector also plays an important role in connecting the regional and global supplies of merchandise exports, which can increase the growth in GDP. However, flood disaster seems to be a major potential threat to the country. We are aware that the effects of flood disaster might vary across regions/states due to heterogeneity in economic, population and geographical structures. However, due to the unavailability of data across regions/states, we are not able to take that into consideration. In order to reduce the issue of heterogeneity, it is pertinent to study the effect of flood across sectors. Hence, this paper looks at the effect of flood on GDP growth across both the manufacturing and agricultural sectors.

Several socio-economic studies on flood have been conducted in Malaysia. Among others are those by Mohd, Alias and Daud (2006), Austin and Baharuddin (2012), Shafie (2009) and Shaari, Karim and Hasan-Basri (2016a, 2016b). However, the first three studies focused more on natural hazards management while the study by Shaari, Karim and Hasan-Basri (2016a) focuses on the effect of flood disaster on GDP growth at the aggregate level. On the other hand, Shaari, Karim and Hasan-Basri (2016b) concentrated on the effect of flood disaster on mining sector GDP growth. However, this paper differs from the above previous studies as it looks at the effect of flood on GDP growth at both the manufacturing and agricultural sectors in Malaysia. To the best of our knowledge, no study has attempted to examine the effects of flood disasters on both the manufacturing and agricultural sectors GDP growth in Malaysia thus filling the gap in the case of Malaysia. The dataset for flood variables used in this paper allows further examination of which flood variables give the most effects on GDP growth in different sectors.

The rest of the paper is organised as follows: Section 2 reviews the literature on the impacts of natural disasters on macroeconomic performance. Section 3 discusses the theoretical framework in formulating the model to be estimated, method used in estimation, and data used in the study to estimate the effects of flood disaster on economic growth. Section 4 discusses the results of the analysis and section 5 concludes the paper.

\section{Literature Review}

The purpose of this section is to review existing literature on the impacts of natural disasters on economic growth. These are studies done previously to analyse the effects of natural disasters on economic growth (among others are Albala-Bertrand, 1993; Hochrainer, 2009; Loayza, Olaberria, Rigolini, \& Christiaensen, 2009; Carter, Little, \& Mogues, 2007).

In order to analyse the impacts of natural disasters in the Philippines and some selected neighbouring countries, Hochrainer (2009) chose Cambodia, Indonesia, The Lao PDR, the Philippines and Viet Nam and reviewed the occurrence of disasters that had been caused by climate and weather between 1990 and 2000. The researcher found that the disasters occurred in all the selected countries on a regular basis with the Philippines being the most affected. Furthermore, this phenomenon has increased in frequency and 
the monetary damage caused by the disasters had been significant in the Philippines. The study found the importance of improving and integrating the national meteorological systems (NMHS) of Southeast Asian countries to address natural disasters.

By analysing 28 cases of large natural disasters in the United Kingdom over two decades (i.e., from 1970 until 1990), Albala-Bertrand (1993) found that disasters did not decrease the level of GDP. In fact, construction activities led to an increase in the gross fixed capital formation. Both trade and public deficits increased sharply while the agricultural sector remained unaffected. However, macroeconomic studies revealed an increase in poverty, a decline in a country's balance of trade, and worsening of fiscal balances which lead to an immediate reduction in economic output caused by natural disasters.

Other than that, Loayza et al. (2009) used cross-country panel data to investigate the impacts of natural disasters on economic growth of 94 countries including developing and developed countries from the year 1961 to 2005. By employing the Generalised Method of Moments on cross country panel data, the authors pointed out three conclusions. First, the impacts of natural disasters vary across sectors of the economy and do not always affect the economy negatively. Second, severe disasters never have a positive impact on the economy while moderate natural disasters can have positive impacts in some sectors. Third, the growth rate of developed countries is less sensitive to natural disasters compared to developing countries. However, the overall effects show that droughts and storms have negative impacts on the GDP growth of the agricultural sector, while floods have a positive effect. Furthermore, Carter et al. (2007) concluded that the major impacts of natural disasters on the agricultural sector are negative. This is because environmental degradation occurs due to natural disasters leading to the vulnerability of agriculture, forestry and rangelands.

Several conclusions can be derived from the discussed literatures. First, empirical literatures on the effects of natural hazards on economic growth have mixed results. Some studies reported positive impacts while others reported the negative. Second, the effects of different types of disasters have different effects on economic growth. Third, the concurrent increases in price and lowered economic growth experienced by the economy resulted in negative and positive effects of natural disasters in the case of sectors. Fourth, there is no study analysing the effects of flood on GDP growth (in the case of sectors) in Malaysia. In the case of Malaysia, the results may be different from those in the literature due to dissimilar economic development and structures. Since the main focus of the paper is to analyse the effects of flood on GDP growth (in the case of sectors), we included four flood variables as independent variables.

\section{Methodology and Data}

Classical theorists set the fundamentals for a number of growth theories. The fundamental for a classical growth model was developed by Smith (1776) who hypothesised a supply side driven model of growth and production function, as shown in Equation (1):

$$
Y=f(L, K, T)
$$

where $\mathrm{Y}$ is output, $\mathrm{L}$ is labour, $\mathrm{K}$ is capital and $\mathrm{T}$ is for technological changes. Output is related to labour, capital and technological changes inputs. Therefore, output growth is 
driven by population growth, investment, technological growth and increases in overall productivity.

\subsection{Economic Growth Framework}

In the framework for investigating growth mechanism, the input-output relationship is characterised by a general production function shown in Equation (2),

$$
Y=T f(K, L)
$$

where $Y$ is the total output level, $T$ is total factor productivity, and $K$ and $L$ are the capital stock and labour, respectively. The differentiation of $Y$ gives Equation (3).

$$
\frac{d Y}{Y}=f_{K} \frac{K}{Y} \frac{d K}{K}+f_{L} \frac{L}{Y} \frac{d L}{L}+\frac{d T}{T}
$$

However, Equation (3) can be interpreted according to Schumpeter's theory of economic development (Schumpeter, 1934), where two types of influence on the evolution of an economy are distinguished. One is the effect of changes in factor availability, the growth component, which is related to the growth rates of labour and capital in the production function. The other is the effect of technological, social changes and the development component (Schumpeter, 1934).

We characterise these components in Equation (4),

$$
Y=F\left(G_{K}, G_{L}\right)
$$

where $\mathrm{Y}$ is GDP growth (\%), $\mathrm{G}_{\mathrm{K}}$ is growth rate of capital stock (\%) and $\mathrm{G}_{\mathrm{L}}$ is growth rate of labour (\%).

There are also many other variables that can be considered to affect GDP growth. However, in this study, we only included additional control variables which are robust and commonly used as control variables in previous studies. Levine and Renelt (1992) identified variables that are robust in determining growth; these are initial level of real GDP per capita and a proxy for human capital. Hence, we incorporated these variables to Equation (4) with the result as shown in Equation (5),

$$
Y=f\left(I G D P, G_{K^{\prime}} G_{L^{\prime}}, H U M A N\right)
$$

where IGDP is initial level of GDP per capita, HUMAN is proxy for human capital. The other variables are as defined before.

Studies by Piazolo (1995), Barro (1995), Andres and Hernando (1999) and Bruno and Easterly (1996) found that inflation is one of the factors that determines economic growth. Inflation not only affects growth and investment but also the efficiency of production.

Hence, incorporating inflation to Equation (5) results in Equation (6),

$$
Y=f\left(I G D P, G_{k}, G_{L}, H U M A N, I N F\right)
$$

where INF is inflation rate (\%) and other variables are as defined before. 
Since the main focus of this paper is to analyse the effects of flood on economic growth, we included flood variables as one of the independent variables.

Floods arguably cause immediate and significant damages to existing capital stocks. Although the loss of existing capital stocks is not directly counted as a decrease in GDP, the damages to capital stock and other crucial infrastructure will disrupt production output and lower economic growth in the short run. In the long run, however, as damaged capital stock is replaced by newer capital, the long run effect could be otherwise (Horwich, 2000).

Noorazuan, Ruslan, Hafizan, Shariffudin and Nazari (2003) suggest that flooding is the most significant natural hazard in Malaysia in terms of frequency of floods, flood duration, population affected, area extent and social economic damages. In another study by Li (1992), duration and frequency of flood were suggested as measures of flood that affects economic growth. Other than that, Soentato and Proverbs (2004), Eves (2004) and Saptutyningsih and Suryanto (2011) used duration of flood as the variable in their study. Additionally, Holway and Burby (1990), Fridgen and Shultz (1999) and Shultz and Fridgen (2001) used frequency of flood as the flood variable in their study. Therefore, in this study, four flood variables were chosen as measurements for flood disaster. The flood variables are flood size, flood duration, flood damage and flood frequency. Figure 2 illustrates the four flood indicators used in this study in the case of flood disasters for the period 1960-2013.

Hence, the final growth equation after including the flood variables is as in Equation (7),

$$
Y=f\left(I G D P, G_{K}, G_{L}, H U M A N, I N F,\right. \text { SIZE, DUR, DAM, FREQ) }
$$

where SIZE is the size of affected area $\left(\mathrm{km}^{2}\right)$, DUR is duration of flood (number of days

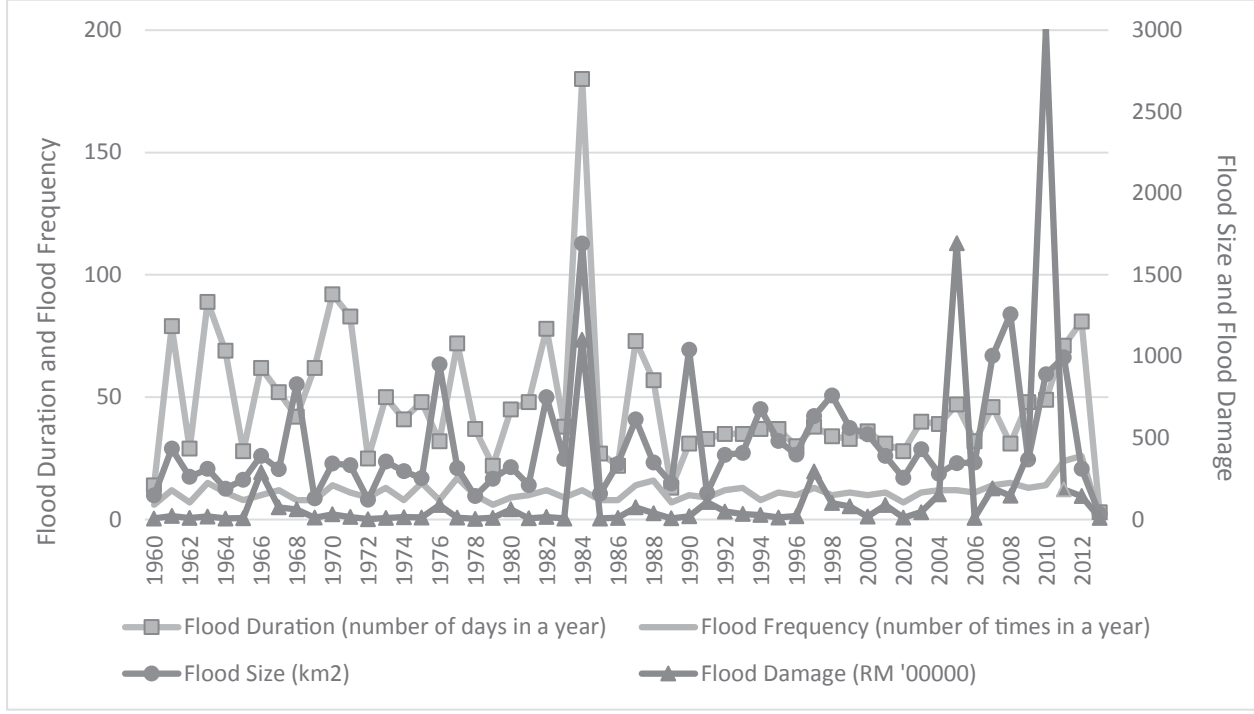

Figure 2. Flood indicators, 1960-2013 
in a year), DAM is total damage cost (RM) and FREQ is frequency of floods (number of times in a year). Other variables are as defined before.

By including an error term, the model and variables for economic growth are derived as in Equation (8):

$$
\begin{aligned}
Y_{t}= & \beta_{0}+\beta_{1} \text { SIZE }_{t}+\beta_{2} \text { DUR }_{t}+\beta_{3} \text { DAM }_{t}+\beta_{4} \text { FREQ }_{t}+\beta_{5} \text { IGDP }_{t}+ \\
& \beta_{6} G_{k t}+\beta_{7} G_{\mathrm{Lt}}+\beta_{8} \text { HUMAN }_{t}+\beta_{9} \text { INF }_{t}+e_{t}
\end{aligned}
$$

\subsection{Research Method}

Prior to testing for cointegration relationship, unit root tests were conducted to check the stationarity, as well as the order of the series variables used, by using the ADF (Dickey \& Fuller, 1979), PP (Phillips \& Perron, 1988) and KPSS (Kwiatkowski, Phillips, Schmidt, \& Shin, 1992) tests. This study employs the Autoregressive Distributed Lag (ARDL) bounds testing approach for cointegration by Pesaran, Shin and Smith (2001) to check for the long run movement of the variables, as well as to consider the robustness of results.

The ARDL bound test (Pesaran et al., 2001) was employed for cointegration analysis as it can be applied irrespective of whether the regressors are purely $I(0)$, purely $I(1)$ or mutually cointegrated. Moreover, it is unnecessary that the order of integration of the underlying regressors be determined prior to testing the existence of a level relationship between two variables (Pesaran et al., 2001). Furthermore, the bounds testing procedure (Pesaran et al., 2001) employed in this study is robust for a small sample study (Pattichis, 1999; Mah, 2000; Tang \& Nair, 2002). Other than that, the bound testing approach is possible even when the explanatory variables are endogenous (Alam \& Quazi, 2003). The ARDL cointegration test assumes that only one long run relationship exists between dependent and exogenous variables (Pesaran et al., 2001). To test whether this is indeed appropriate in the current application, the entire variables are changed to be dependent variables so as to compute the F-statistic for the respective joint significance in the ARDL models.

The bound test is basically computed based on an estimated error correction version of autoregressive distributed lag (ARDL) model by Ordinary Least Squares (OLS) estimator (Pesaran et al., 2001). In this study, the ARDL bounds equation for GDP growth is estimated as shown in Equation (9).

$$
\begin{aligned}
\Delta Y_{t}=\alpha_{0}+\sum_{i=0}^{p} & \rho_{i} \Delta S I Z E_{t-i}+\sum_{i=0}^{p} \varphi_{i} \Delta D U R_{t-i}+\sum_{i=0}^{p} \omega_{i} \Delta D A M_{t-i}+\sum_{i=0}^{p} \vartheta_{i} \Delta F R E Q_{t-i} \\
& +\sum_{i=0}^{p} \beta_{i} \Delta Y_{t-i}+\sum_{i=0}^{p} \mu_{i} \Delta G_{K_{t-i}}+\sum_{i=0}^{p} \gamma_{i} \Delta I G D P_{t-i}+\sum_{i=0}^{p} \delta_{i} \Delta G_{L_{t-i}} \\
& +\sum_{i=0}^{p} \theta_{i} \Delta H U M A N_{t-i}+\sum_{i=0}^{p} \pi_{i} \Delta I N F_{t-i}+\sigma_{1} S I Z E_{t-1}+\sigma_{2} D U R_{t-1} \\
& +\sigma_{3} D A M_{t-1}+\sigma_{4} F R E Q_{t-1}+\sigma_{5} Y_{t-1}+\sigma_{6} G_{K_{t-1}}+\sigma_{7} I G D P_{t-1}+\sigma_{8} G_{L_{t-1}} \\
& +\sigma_{9} \text { HUMAN }_{t-1}+\sigma_{10} I N F_{t-1}+\varepsilon_{t}
\end{aligned}
$$


where, $Y_{t}$ is GDP growth, SIZE $E_{t-i}$ is size of area affected, DUR $R_{t-i}$ is duration of flood, DAM $M_{t-i}$ is total damaged cost, FREQ ${ }_{t-i}$ is frequency of flood, $G_{K_{t-i}}$ is capital growth, $G_{L_{t-i}}$ is labour growth, IGDP $\mathrm{t}_{\mathrm{t}-\mathrm{i}}$ is initial GDP, HUMAN $\mathrm{t}_{\mathrm{t}-\mathrm{i}}$ is human capital, INF $\mathrm{F}_{\mathrm{t}-\mathrm{i}}$ is inflation, $p$ is the optimal lag length and $\Delta$ refers to the first difference of variables. The first part of Equation (9) with $\rho, \omega, \vartheta, \beta, \mu, \gamma, \delta, \theta$ and $\pi$ refer to the short run. The rest with $\sigma_{k}$ are the long run parameters.

The hypotheses for testing the existence of any long run cointegration among the proposed variables in this study are $H_{0}: \sigma_{1}=\sigma_{2}=\sigma_{3}=\sigma_{4}=\sigma_{5}=\sigma_{6}=\sigma_{7}=\sigma_{8}=\sigma_{9}=\sigma_{10}=0$ and $\mathrm{H}_{1}$ : at least one of $\sigma_{\mathrm{i}}$ is not equal to zero. Thus, this is the joint null hypothesis of no cointegration against the existence of a valid relationship between GDP growth and the set of explanatory regressors for both the agricultural and manufacturing sectors, separately. The new OLS output gives the value of the F-statistic that is represented by $F\left(Y_{t} \mid S_{I Z E_{t}}, D R_{t}, D M_{t}, F_{R E Q}, G_{k t}, G_{t t}, H_{U M A N}, I G D P_{t}, I N F_{t}\right)$. Under the conventionally used level of significance such as one percent and five percent, if the F-statistic exceeds upper critical bound, the null hypothesis of no cointegrating relation can therefore be rejected. If the test statistic (F-statistic) falls below the lower critical bound, the null of non-cointegration cannot be rejected. Finally, if the F-statistic falls between the bounds, the test is inconclusive (Pesaran et al., 2001).

When the results of F-statistics in the first step support the evidence of the existence of cointegration between variables, the second step of ARDL approach is to estimate the long run coefficient. In this study, the model for cointegration equation for GDP growth is shown in Equation (10).

$$
\begin{aligned}
Y_{t}=\alpha_{10,0}+ & \sum_{i=1}^{p} a_{11, i} \operatorname{SIZE}_{t-i}+\sum_{i=1}^{p} a_{12, i} D U R_{t-i}+\sum_{i=1}^{p} a_{13, i} D A M_{t-i}+\sum_{i=1}^{p} a_{14, i} F_{R E Q_{t-i}} \\
& +\sum_{\substack{i=1 \\
p}}^{p} a_{15, i} G_{K_{t-i}}+\sum_{i=1}^{p} a_{16, i} I G D P_{t-i}+\sum_{i=1}^{p} a_{17, i} G_{L_{t-i}}+\sum_{i=1}^{p} a_{18, i} H_{U M A N} N_{t-i} \\
& +\sum_{i=1}^{p} a_{19, i} I N F_{t-i}+\varepsilon_{t}
\end{aligned}
$$

The study identifies the existence of a long run relationship between GDP growth and flood variables. In particular, the existence of a long run relationship between economic growth and flood variables was tested for the agricultural and manufacturing sectors, respectively. In doing so, the study is able to determine whether the flood measurement has different effects across the sectors. If cointegration is detected between series, it suggests a long run relationship between the variables, and there must be a short run relationship between them. The third step of ARDL approach is to estimate for any short run relationship. The error correction model (ECM) is used to evaluate the short run relationship between the cointegrated series.

Relying on the presence of a cointegrating relationship, the error correction model (ECM) can be written as in Equation (11): 


$$
\begin{aligned}
Y_{t}=\alpha_{10,0}+ & \sum_{i=1}^{p} a_{11, i} S I Z E_{t-i}+\sum_{i=1}^{p} a_{12, i} D U R_{t-i}+\sum_{i=1}^{p} a_{13, i} D A M_{t-i}+\sum_{i=1}^{p} a_{14, i} F R E Q_{t-i} \\
& +\sum_{i=1}^{p} a_{15, i} G_{K_{t-i}}+\sum_{i=1}^{p} a_{16, i} I G D P_{t-i}+\sum_{i=1}^{p} a_{17, i} G_{L_{t-i}}+\sum_{i=1}^{p} a_{18, i} H_{U M A N} N_{t-i} \\
& +\sum_{i=1}^{p} a_{19, i} I N F_{t-i}+\varphi E C T_{t-1}+\varepsilon_{1 t}
\end{aligned}
$$

where $\phi \mathrm{ECT}_{\mathrm{t}-1}$ is the error correction term. All other variables are as defined before.

In the study, lag order is selected using the minimum values of Akaike Information Criterion (AIC). Lag orders are selected using AIC because results are usually better and more consistent than utilising other information criteria (Lutkepohl, 2006). The diagnostic test and stability test of long run and short run parameters are tested by using the cumulative sum of recursive residuals (CUSUM) and the cumulative sum of squares (CUSUMsq) of recursive residuals for both the agricultural and manufacturing sectors.

\subsection{Data}

This study examined the effects of flood on GDP growth for both the agricultural and manufacturing sectors. For this purpose, the yearly data for GDP growth (percent), initial GDP per capita (RM), labour growth (percent), capital growth (percent), human capital (tertiary enrolment, percent), inflation (consumer price index) and flood variables: (1) frequency of floods (number of times in a year), (2) size of the affected area $\left(\mathrm{km}^{2}\right),(3)$ total damage cost (RM) and (4) duration of flood (number of days in a year) were used.

All data were collected from the period between 1960 and 2013. In particular, data collected from the Reuters Database are GDP growth, labour growth, capital growth, initial GDP per capita, human capital and inflation. On the other hand, data for flood variables (size of the affected area, frequency of flood, duration of flood and total damage cost) were collected from the Department of Irrigation and Drainage Malaysia.

\section{Results and Discussion}

Table 1 presents the results of Augmented Dickey-Fuller (ADF) test, Phillips-Perron (PP) test and Kwiatkowski-Phillips-Schmidt-Shin (KPSS) test for all series in levels and firstdifferences using the annual data from 1960 until 2013. The results show that the null hypothesis of unit root at the five percent and one percent critical value for all series can be rejected, except for Inflation, Human Capital and Initial GDP. Nevertheless, the null hypothesis is rejected at the five percent and one percent critical value for the series in the first difference. The results in Table 1 show that there is a mixture of $I(0)$ and $I(1)$ of underlying regressors. Therefore, it is suitable to use the ARDL approach.

The lag length selection test is displayed in Table 2 for both the agricultural and manufacturing sectors. The lag length is selected using the minimum values of AIC (Shrestha \& Chowdhury, 2005). In this study, the maximum order of lag in the ARDL is 
Table 1. Unit root test

\begin{tabular}{|c|c|c|c|c|c|c|}
\hline \multirow{2}{*}{ Variable } & \multicolumn{2}{|c|}{ ADF } & \multicolumn{2}{|c|}{ PP } & \multicolumn{2}{|c|}{ KPSS } \\
\hline & Level & 1st diff. & Level & 1st diff. & Level & 1st diff. \\
\hline Capital agricultural & $-9.572 * * *$ & $-8.946 * * *$ & $-9.748 * * *$ & $-6.792 * * *$ & $0.196 * *$ & 0.084 \\
\hline Capital manufacturing & $-8.093 * * *$ & $-9.151 * * *$ & $-8.016 * * *$ & $-7.777 * * *$ & $0.057 * * *$ & 0.070 \\
\hline Flood size & $-7.674 * * *$ & $-8.669 * * *$ & $-7.675^{* * *}$ & $-5.334 * * *$ & $0.038^{* * *}$ & 0.064 \\
\hline Flood damage & $-7.520 * * *$ & $-11.257 * * *$ & $-7.327 * * *$ & $-8.787 * * *$ & 0.114 & 0.039 \\
\hline Flood duration & $-8.156 * * *$ & $-7.194 * * *$ & $-8.164 * * *$ & $-6.352 * * *$ & $0.061 * * *$ & 0.094 \\
\hline Flood frequency & $-6.923^{* * *}$ & $-8.255^{* * *}$ & $-6.878 * * *$ & $-4.214 * * *$ & 0.110 & 0.065 \\
\hline Labour agricultural & $-8.929 * * *$ & $-4.629 * * *$ & $-9.036 * * *$ & $-6.042 * * *$ & $0.074 * * *$ & 0.070 \\
\hline Labour manufacturing & $-7.367 * * *$ & $-7.704 * * *$ & $-7.393 * * *$ & $-5.872 * * *$ & $0.087 * * *$ & 0.057 \\
\hline Growth agricultural & $-7.669 * * *$ & $-9.042 * * *$ & $-10.172 * * *$ & $-8.929 * * *$ & $0.164 * * *$ & 0.055 \\
\hline Growth manufacturing & $-5.115^{* * *}$ & $-8.434 * * *$ & $-5.442 * * *$ & $-9.221 * * *$ & $0.129 *$ & 0.074 \\
\hline Inflation & -2.951 & $-5.917 * * *$ & -2.653 & $-5.917 * * *$ & $0.074 * * *$ & 0.050 \\
\hline Human capital & -1.158 & $-5.760 * * *$ & -1.175 & $-5.618 * * *$ & 0.243 & 0.074 \\
\hline Initial GDP & -0.887 & $-7.480 * * *$ & -0.887 & $-7.483^{* * *}$ & $0.196 * *$ & 0.084 \\
\hline
\end{tabular}

Note: ${ }^{*}, * *$ and $* * *$ are statistically significant at 10 percent, five percent and one percent, respectively.

Table 2. Bound test and lag length selection

\begin{tabular}{lcccc}
\hline \multirow{2}{*}{ Sector } & \multicolumn{3}{c}{ Order of lags } & F-statistics \\
\cline { 2 - 4 } & 1 & 2 & 3 & \\
\hline Agricultural & 6.425 & 5.635 & 5.684 & $4.318^{* * *}$ \\
Manufacturing & 5.639 & 5.224 & 5.504 & $3.762^{* * *}$ \\
\hline
\end{tabular}

Notes: $(2.50,3.68),(2.04,2.08)$ and $(1.80,2.80)$ at the one, five and 10 percent levels of significance, respectively.

$*, * *$ and $* * *$ are statistically significant at 10 percent, five percent and one percent, respectively.

2 since the value of 5.635 and 5.224 are the minimum value of AIC for both agricultural and manufacturing sectors, respectively. By using the lag length of 2, Equation (10) was estimated to examine the long run relationship among the variables for both the agricultural and manufacturing sectors.

The F-statistics of the bound test for both the agricultural and manufacturing sectors are 4.318 and 3.762, respectively. Since the values are above the one percent upper bound critical value of 3.68 (Pesaran et al., 2001), the null hypothesis of no long run cointegration among the variables can be rejected. Hence, the results show that there is a long run relationship between GDP growth and flood variables (flood size, flood duration, flood damage and flood frequency) in both the agricultural and manufacturing sectors.

Table 3 shows the main empirical findings of the estimated long run coefficients for the equation of both the agricultural and manufacturing sectors. The significant 
Table 3. The estimated long run coefficient for GDP growth by sectors

\begin{tabular}{lcc}
\hline Variable & Agricultural growth & Manufacturing growth \\
\hline Constant & 0.087 & 0.011 \\
& $(1.675)$ & $(1.134)$ \\
Flood size & -0.216 & -0.027 \\
Flood damage & $\left(-3.061^{* * *}\right)$ & $(-1.299)$ \\
& -0.177 & 0.650 \\
Flood duration & $\left(-3.209^{* * *}\right)$ & $\left(1.953^{*}\right)$ \\
& 0.056 & 0.003 \\
Flood frequency & $(0.938)$ & $(0.921)$ \\
& 0.018 & 0.004 \\
Capital & $(0.528)$ & $(1.500)$ \\
& -0.319 & -0.161 \\
Labour & $(-1.523)$ & $\left(-2.431^{* *}\right)$ \\
& -0.027 & 0.157 \\
Initial GDP & $(-1.729 *)$ & $\left(2.599^{* *}\right)$ \\
Human & -0.016 & -0.013 \\
Inflation & $(-0.716)$ & $(-1.453)$ \\
& 0.099 & 0.211 \\
Sensitivity analysis & $(0.263)$ & $(1.108)$ \\
Serial correlation Lagrange multiplier (LM) & 0.251 \\
Heteroscedasticity & 0.086 & $\left(1.736^{*}\right)$ \\
\hline Normal form & $(0.551)$ & \\
& & $0.365(0.550)$ \\
& $0.362(0.552)$ & $0.033(0.857)$ \\
& $0.769(0.387)$ & $0.729(0.397)$ \\
\hline
\end{tabular}

Notes: $t$-values are given in parentheses.

${ }^{*}, * *$ and ${ }^{* * *}$ are statistically significant at 10 percent, five percent and one percent, respectively.

variables, which appear to affect agricultural growth in the long run, are Flood Size, Flood Damage and Labour. The coefficient of the variables is significant at least at the 10 percent level. In contrast, the significant variables which appear to affect the manufacturing growth in the long run are Flood Damage, Capital, Labour and Inflation. The coefficient of the variables is significant at least at the five percent level. The results of diagnostic tests reported in the lower segment of Table 3 indicate no serial correlation. The residual term is normally distributed and there is an absence of white heteroscedasticity for both the agricultural and manufacturing equations.

The results show a significantly positive relationship between total damage cost and GDP growth in the manufacturing sector. The results indicate that a one percent increase 
in total damage cost will increase GDP growth by 0.65 percent. The reason is due to the purchasing of new machines and replacement of old technologies. The replacement makes production of goods more efficient, and hence, generates GDP growth in the long run. However, the long run results for the manufacturing sector are different from the results for the agricultural sector.

In the case of the agricultural sector, the results show a negative relationship between size of the affected area and total damage cost with GDP growth. The bigger the area affected and the larger the damage cost, the higher the fall will be in GDP growth. The results indicate that a one percent increase in the size of affected area decreases GDP growth by 0.22 percent. Further, the results also indicate that a one percent increase in total damage cost decreases GDP growth by 0.17 percent. This is because the loss of output in the agricultural sector could not be replaced immediately after flood due to low productivity in the agricultural sector. This low productivity in the agricultural sector is evident in Malaysia because it is not as capital intensive as in the manufacturing sector. Hence, there are not many significant production assets to be repaired and no newer technologies to be replaced that can enhance production as in the case of the manufacturing sector.

In summary, among all the four flood variables, two have significant relationships with GDP growth in both sectors in Malaysia in the long run. Both Flood Size and Flood Damage negatively affect GDP growth in the agricultural sector, while positively affecting GDP growth in the manufacturing sector. Meanwhile, both Flood Duration and Flood Frequency have insignificant relationships with GDP growth in both sectors in Malaysia in the long run. From the findings, it is clear that flood has impacts on GDP growth in both sectors in the long run. In this case, Flood Size and Flood Damage were expected to affect the agricultural sector mostly in Kedah compared to Penang which focuses on the manufacturing sector. Meanwhile, Flood Damage was expected to affect the manufacturing sector mostly in several states such as Perlis, Penang, Terengganu, Pahang, Johor and Sabah. From the discussion above, it is convincingly proven that flood disaster affects the GDP growth of both the manufacturing and agricultural sectors in the long run in the case of Malaysia.

In the case of Labour, the results show a significant negative relationship between growth of labour and GDP growth in the agricultural sector. This is due to the improvement in technologies used. The use of machines in agricultural sector production can generate growth. This is consistent with Matsuyama's argument on the economy which has a comparative advantage in agriculture where improvement in the productivity of agriculture by hiring more labour does not seem to help the growth and structural evolution of the economy (Matsuyama, 1992). In contrast, the results for the manufacturing sector show a significantly positive relationship between growth of labour and GDP growth. This is because an increasing number of labour employed in the sector will increase production capacity and lead to positive economic growth in the long run.

Meanwhile, the results show a significant positive relationship between inflation and GDP growth in the manufacturing sector. The results indicate that a one percent increase in inflation increases GDP growth by 0.25 percent. This is because of an 
increase in demand with no spare capacity and the economy is working on full employment level. Therefore, any further gain in growth comes at the cost of rising inflation. This result is supported by Sweidan (2004), who found a significant positive relationship between the two variables in the long run. In the case of Malaysia, inflation is insignificant with GDP growth of the agricultural sector in the long run.

In the case of Capital Growth, the results show a significant negative relationship with GDP growth in the manufacturing sector. The results indicate that a one percent increase in capital decreases GDP growth by 0.16 percent. The result is in contrast with the findings of Chow (1993), who found that capital growth contributes to the growth of China's economy in five major sectors including the agricultural and manufacturing sectors in the long run. However, the findings of Potiowsky and Qayum (1992) do not show any significant effects of domestic capital formation on economic growth in the long run. This is due to growth having more causal effect on capital formation rather than capital formation on growth. In the case of Malaysia, capital growth in the agricultural sector is insignificant with GDP growth in the long run.

The results of the estimated short run coefficient for GDP growth obtained for the agricultural and manufacturing sectors are presented in Table 4. The significant variables which appear to affect agricultural growth in the short run are Flood Size, Flood Damage, Initial GDP, Human Capital and Inflation. The coefficient of the variables is significant at least at the 10 percent level. Besides, the significant variables which appear to affect manufacturing growth in the short run are Flood Size, Flood Frequency, Flood Damage, Capital, Initial GDP, Human Capital and Inflation. The coefficient of the variables is significant at least at the 10 percent level.

Table 4. The estimated short run coefficient for GDP growth by sectors

\begin{tabular}{|c|c|c|c|c|}
\hline \multirow{2}{*}{ Variable } & \multicolumn{2}{|c|}{ Agricultural growth } & \multicolumn{2}{|c|}{ Manufacturing growth } \\
\hline & Coefficient & $t$-statistics & Coefficient & $t$-statistics \\
\hline Constant & 0.313 & $1.214^{* *}$ & 0.218 & 1.214 \\
\hline Flood size & 0.121 & $1.342 * * *$ & 0.337 & $1.353^{*}$ \\
\hline Flood size $_{t-1}$ & 0.090 & $2.918^{* * *}$ & 0.131 & $1.729 *$ \\
\hline Flood damage & 0.291 & $2.574 * * *$ & 0.199 & $2.717^{* *}$ \\
\hline Flood damage $_{t-1}$ & 0.028 & $2.798 * * *$ & - & - \\
\hline Flood duration & -0.333 & -0.085 & -0.027 & -0.853 \\
\hline Flood duration $_{\mathrm{t}-1}$ & - & - & -0.089 & -2.058 \\
\hline Flood frequency & 0.027 & 0.523 & 0.058 & $2.367^{* *}$ \\
\hline Capital & -0.083 & -0.833 & -0.813 & $-1.899 *$ \\
\hline Labour & -0.018 & -0.112 & 0.002 & 1.175 \\
\hline Initial GDP & 0.005 & $1.485^{* *}$ & 0.014 & $6.062 * * *$ \\
\hline Initial $\mathrm{GDP}_{\mathrm{t}-1}$ & 0.071 & 1.777 & - & - \\
\hline Human & 0.028 & $3.498 * * *$ & 0.091 & $4.721 * * *$ \\
\hline Inflation & -0.215 & $-1.396 *$ & 0.122 & $2.745^{* * *}$ \\
\hline Inflation $_{\mathrm{t}-1}$ & -0.571 & 1.918 & - & - \\
\hline Error correction term $\left(\mathrm{ECT}_{\mathrm{t}-1}\right)$ & -0.017 & $-5.067 * * *$ & -0.034 & $-2.166 * *$ \\
\hline
\end{tabular}

Note: ${ }^{*}, * *$ and $* * *$ are statistically significant at 10 percent, five percent and one percent, respectively. 
The results for the size of affected area and total damage cost show positively significant relationships with GDP growth in the agricultural sector. The results indicate that a one percent increase in size and damage increases GDP growth by 0.12 percent and 0.29 percent, respectively. The results also indicate that a one percent increase in the size of affected area and total damage cost of the previous year will influence the increase in GDP growth of the following year by 0.09 percent and 0.03 percent, respectively. The result is similar to that of the manufacturing sector, where size of affected area, damage cost and frequency show positive significant relationships with GDP growth. The results indicate that a one percent increase in size of affected area, total damage cost and frequency of flood will increase GDP growth by 0.33 percent, 0.19 percent and 0.06 percent, respectively. The results also indicate that a one percent increase in the size of affected area of the previous year will influence the increase in GDP growth of the following year by 0.13 percent.

In the case of the agricultural sector, size of affected area and total damage cost were expected to negatively affect GDP growth of the agricultural sector. This situation is due to the total loss and damaged crops as consequences of flood. In this case, however, the result indicates that size of affected area and total damage cost positively affects GDP growth of the agricultural sector. Nonetheless, our results are in contrast with the long run findings, and this is due to the immediate recovery efforts such as purchasing new crops. The immediate purchase seems to contribute to the positive GDP growth in the short run.

Similarly, size of affected area and total damage cost were expected to negatively affect GDP growth of the manufacturing sector, and this is due to damages to manufacturing stockpiles and temporary disruption in production as the consequences of flood. However, the results indicate that size of affected area and total damage cost positively affects GDP growth of the manufacturing sector. The positive effect is due to the immediate replacement of new machines in order to continue production, and thus, generates GDP growth in the short run. The finding is supported by Horwich (2000), who found that a disaster would cause disruptions in production and slow down output and growth.

However, during a phase of rebuilding where stock of capital is used, there is increased activity leading to more growth. After damages and destroyed physical capital have been rebuilt, output will increase more as a result of the updated machinery in the short run. The finding is also supported by Noy and $\mathrm{Vu}$ (2010), who found that disasters result in lower output growth but the disasters that destroyed capital and property appear to boost the economy in the short run. Therefore, the immediate recovery contributes to positive GDP growth in the short run.

Meanwhile, the results show a positive relationship between frequency of flood and GDP growth in the manufacturing sector. In this study, frequency of flood was expected to affect GDP growth negatively in the manufacturing sector due to the frequently temporary disruption of production as a consequence of flood. However, our results indicate that the frequency of flood affects GDP growth positively in the manufacturing sector due to the frequent replacements of machines with those with newer technologies making production even more efficient to cope with the demand. 
This therefore contributes positively to GDP growth in the manufacturing sector in the short run.

In summary, among all the four flood variables, three have significant relationships between flood and sectors' GDP growth in Malaysia in the short run. For instance, Flood Size and Flood Damage positively affected GDP growth of the manufacturing and agricultural sectors in the short run. Meanwhile, Flood Frequency positively affected GDP growth of the manufacturing sector. From the findings, it is clear that floods positively affect the two sectors in the short run. The positive effect is due to the immediate recovery such as purchasing of new plants for the agricultural sector and immediate and frequent replacement with new machines with latest technologies for the manufacturing sector. Thus, these generate GDP growth in the short run.

In the case of Initial GDP, the results show a significant positive relationship between Initial GDP and GDP growth in both sectors. The results indicate that a one percent increase in Initial GDP will increase GDP growth by 0.005 percent and 0.01 percent in the agricultural and manufacturing sectors, respectively. In the case of Malaysia, the manufacturing sector's increase is higher than the agricultural sector. This is due to the knowledge gap between actual and potential knowledge or capacity. The larger the knowledge gap, the easier for a country to increase its productivity by imitating, adapting and learning technology from leading countries. This is consistent with the finding of the study by Levine and Renelt (1992) which revealed the positive relationship between initial real GDP and economic growth.

Meanwhile, the results show a significant negative relationship between inflation and GDP growth in the agricultural sector. The results indicate that a one percent increase in inflation will decrease GDP growth by 0.21 percent. In contrast, the results show a significant positive relationship between inflation and GDP growth in the manufacturing sector. The results indicate that a one percent increase in inflation will increase GDP growth by 0.12 percent. This is due to the shortage of goods and services in the economy from the manufacturing sector. Several supply and demand factors could also be responsible for the increase in inflation in Malaysia.

This result is consistent with the findings of Fischer (1993), De Gregorio (1996) and Kormendi and Meguire (1985). The authors presented evidence of a negative relationship between growth and inflation in the short run. However, in the studies by Sarel (1995), Mallik and Chowdhury (2001), and Ericsson, Irons and Tryon (2001), there was a confirmed positive relationship between economic growth and inflation in the short run. The result was also confirmed by Barro (1995), who found that the relationship might not be linear. Hence, the relationship can work both ways.

In the case of Capital Growth, the results show a significant negative relationship with GDP growth in the manufacturing sector. The results indicate that a one percent increase in capital growth will decrease GDP growth by 0.81 percent. The result is consistent with the finding of Blomström, Lipsey and Zejan (1996) which showed a negative relationship between capital growth and economic growth in the short run. This is due to the effects that could be more or less permanent, depending on the extent to which technological innovation is embodied in new capital. In the case of Malaysia, capital growth in the agricultural sector is insignificant with the GDP growth in the short run. 
Besides, the results showed positively significant relationships between human capital and GDP growth in both sectors. To be more specific, the results indicate that a one percent increase in human capital will increase GDP growth by 0.03 percent and 0.09 percent in the agricultural and manufacturing sectors, respectively. In the case of Malaysia, the manufacturing sector increased by 0.06 percent compared to the agricultural sector. This is because an educated labour force is better at learning, creating and implementing new technologies. This is consistent with Benhabib and Spiegel (1994) and Cohen and Soto (2007). The authors found that human capital has a positive effect on economic growth.

In this case, ECT causes GDP growth to converge to its long run equilibrium path in response to changes in the exogenous variables. If ECT is positive or less than -2 , this will cause the GDP growth to diverge. If the value is between -1 and -2 , the ECT will reduce fluctuations in GDP growth to be around its equilibrium path. ECT is between 0 and -1 for both the agricultural and manufacturing sectors, as shown in Table 4 . This implies that the error correction process converges to the equilibrium path. In our case, ECT is significant at one percent and five percent for the agricultural and manufacturing sectors, respectively. This confirms the existence of an established cointegration and also implies that a deviation from the equilibrium level of GDP growth during the current year will be corrected by 1.7 percent and 3.4 percent for the agricultural and manufacturing sectors, respectively, in the next year.

The stability tests were conducted to examine the stability of the long run and short run parameters. In doing so, cumulative sum (CUSUM) and cumulative sum of squares (CUSUMsq) tests were tested for the agricultural and manufacturing models. Pesaran and Shin (1998) have suggested to check the stability of short run and long run estimates through CUSUM and CUSUMsq tests. Appendices 1 to 4 specify that plots for both CUSUM and CUSUMsq for both manufacturing and agricultural sectors are between critical boundaries at five percent level of significance. These confirm the accuracy of the short run and long run parameters which have impacts on GDP growth in the agricultural and manufacturing sectors in Malaysia. Furthermore, both the tests also verify the stability of the ARDL model for structural stability. This indicates that the model is well specified.

\section{Conclusion}

This paper examines the impacts of flood on economic growth (GDP growth in the agricultural and manufacturing sectors) in Malaysia from 1960 until 2013. The paper explores the existence of the short run and long run relationships between GDP growth and flood variables in the case of Malaysia. The paper used the ARDL bounds testing approach to cointegration and error correction model (ECM) for the short run relationship. ADF, PP and KPSS unit root tests examine stationarity of the series. The results show that the series are cointegrated.

In the case of Malaysia, flood negatively affects economic growth in the long run. On the other hand, flood positively affects economic growth in the short run. The findings suggest that there are short run and long run relationships between economic growth and flood in the agricultural and manufacturing sectors. In the long run, size 
of the affected area was found to affect agricultural growth negatively. In contrast, size of the affected area was shown to positively affect agricultural growth in the short run. This result is consistent with the findings of Benson and Clay (1998). The researchers found that the impacts of floods could be quite significant for agricultural growth in both the short run and long run. Meanwhile, total damage cost positively affects the manufacturing growth in both the short run and long run. This result is similar to the conclusion made by Das (2003), who stated that natural disasters caused loss of potential production due to disturbed flow of goods and services, lost production capacities and increased costs of production. Such indirect impacts appear to progressively generate growth in the long run.

The results of the study have important implications for the agricultural and manufacturing sectors. First, the agricultural sector should develop strategies to overcome the negative impacts of flood in the long run such as allocating new areas which are out of flood prone areas so that the impacts of flood on the sector can be minimised in the long run. Moreover, new areas to keep agricultural inventories should be allocated at free flood zones so that food production will not be disrupted in the short run. Second, the manufacturing sector should prepare sufficient inventories to avoid disruptions in production in the short run. Furthermore, manufacturing inventories should be allocated at free flood zones so that the manufacturing sector will have enough inventories to supply in both the short run and long run whenever flood occurs.

\section{References}

Alam, M.I., \& Quazi, R.M. (2003). Determinants of capital flight: An econometric case study of Bangladesh. International Review of Applied Economics, 17(1), 85-103.

Albala-Bertrand, J.M. (1993). Natural disaster situations and growth: A macroeconomic model for disaster impacts. World Development, 21(9), 1417-1434.

Andres, J., \& Hernando, I. (1999). Does inflation harm economic growth? (European Central Bank Working Paper Series). Frankfurt: European Central Bank.

Austin, O.C., \& Baharuddin, A.H. (2012). Risk in Malaysian agriculture: The need for a strategic approach and a policy refocus. Kajian Malaysia (Journal of Malaysian Studies), 30(1), 21-50.

Barro, R.J. (1995). Determinants of economic growth: A cross-country empirical study (NBER Working Paper No. 5145). Cambridge, MA: National Bureau of Economic Research.

Benhabib, J., \& Spiegel, M. (1994). The role of human capital in economic development: Evidence from aggregate cross country data. Journal of Monetary Economics, 34(2), 143-173.

Benson, C., \& Clay, E.J. (1998). Understanding the economic and financial impacts of natural disasters. Journal of Monetary Economics, 21(2), 13-36.

Blomström, M., Lipsey, R.E., \& Zejan, M. (1996). Is fixed investment the key to economic growth? The Quarterly Journal of Economics, 111(1), 269-276.

Bruno, M., \& Easterly, W. (1996). Inflation crises and long run growth. Journal of Monetary Economics, 41(1), 3-26.

Carter, M.R., Little, P., \& Mogues, T. (2007). Poverty traps and natural disasters in Ethiopia and Honduras. World Development, 35(5), 835-856.

Center for Research of the Epidemiology of Disasters (CRED). The International Disaster Database. http://www.emdat.be/database

Chow, G.C. (1993). Capital formation and economic growth in China. The Quarterly Journal of Economics, 108(3), 809-842. 
Cohen, D., \& Soto, M. (2007). Growth and human capital: Good data, good results. Journal of Economic Growth, 12(1), 51-76.

Dickey, D.A. \& Fuller, W.A. (1979). Distribution of the estimators for autoregressive time series with a unit root. Journal of the American Statistical Association, 74(366), 427-431.

Das, H.P. (2003). Introduction. In World Meteorological Organization, Agrometeorology related to extreme events, WMO No. 943 (pp. 1-6). Geneva: World Meteorological Organization.

De Gregorio, J. (1996). Inflation, taxation, and long run growth. Journal of Monetary Economics, 31(3), 271-298.

Ericsson, N.R., Irons, J.S., \& Tyron, R.W. (2001). Output and inflation in the long run. Journal of Applied Econometrics, 16(3), 241-253.

Eves, C. (2004). The impact of flooding on residential property buyer behaviour: An England and Australian comparison of flood affected property. Structural Survey, 22(2), 84-94.

Fischer, S. (1993). The role of macroeconomic factors in growth. Journal of Monetary Economics, 32(3), 485-512.

Fridgen, P., \& Shultz, S. (1999). The threat of flooding on housing values in Fargo/Moorhead. In E. Kendy (Ed.), Science into policy: Water in the public realm (Proceedings, Specialty Conference, 30 June -2 July 1999, Bozeman, Montana, pp. 77-82). Herndon, Virginia: American Water Resources Association.

Hochrainer, S. (2009). Assessing the macroeconomic impacts of natural disasters: Are there any? (World Bank Policy Research Working Paper No. 4968). Washington DC: World Bank.

Holway, J.M., \& Burby, R.J. (1990). The effects of floodplain development controls on residential land values. Land Economics, 66(3), 259-271.

Horwich, G. (2000). Economic lessons of the Kobe earthquake. Economic Development and Cultural Change, 48(3), 521-542.

Kormendi, R.C. \& Meguire, P.G. (1985). Macroeconomic determinants of growth. Journal of Monetary Economics, 16(2), 141-163.

Kwiatkowski, D., Phillips, P.C.B., Schmidt, P. \& Shin, Y. (1992). Testing the null hypothesis of stationarity against the alternative of a unit root. Journal of Econometrics, 54(1-3), 159-178.

Levine, R., \& Renelt, D. (1992). A sensitivity analysis of cross-country growth regressions. American Economic Review, 82(4), 942-963.

Li, F. (1992). Grey system theory and its application. Paper presented at the International Symposium, Xinjiang Institute of Ecology and Geography, Urumqi, China.

Lutkepohl, H. (2006). Structural vector autoregressive analysis for cointegrated variables (European University Institute Working Paper No. 2005/2). San Domenico, Italy: European University Institute.

Loayza, N., Olaberria, E., Rigolini, J., \& Christiaensen, L. (2009). Disasters and growth: Going beyond the averages (World Bank Policy Research Working Paper No. 4980). Washington DC: World Bank.

Mah, J.S. (2000). An empirical examination of the disaggregated import demand of Korea-the case of information technology products. Journal of Asian Economics, 11(2), 237-244.

Mallik, G., \& Chowdhury, A. (2001). Inflation and economic growth: Evidence from South Asian countries. Asia-Pacific Development Journal, 8(1), 123-135.

Matsuyama, K. (1992). Agricultural productivity, comparative advantage and economic growth. Journal of Economic Theory, 58(2), 317-334.

Mohd, M.S., Alias, B., \& Daud, D. (2006). GIS analysis for flood hazard mapping: Case study Segamat, Johor, West Malaysia. Paper presented at the Seminar Nasional GIS 2006: Geographic Information System Application for Mitigation in Natural Disaster, 29 November, Universiti Indonesia, Jakarta.

Noorazuan, M.H. (2006). Urban hydrological changes in the Sankey Brook catchment. Unpublished PhD thesis. University of Manchester, Manchester, United Kingdom. 
Noorazuan, M.H., Ruslan, R., Hafizan, H., Shariffudin, M., \& Nazari, J. (2003). GIS application in evaluating land use-land cover change and its impact on hydrological regime in Langat River Basin, Malaysia. Paper presented at the 2nd Annual Asian Conference of Map Asia 2003, 1415 October, PWTC Kuala Lumpur.

Noy, I., \& Vu, T.B. (2010). The economics of natural disasters in a developing country: The case of Vietnam. Journal of Asian Economics, 21(4), 345-354.

Pattichis, C.A. (1999). Price and income elasticities of disaggregated import demand: Results from UECMs and an application. Journal of Applied Econometrics, 31(9), 1061-1071.

Pesaran, M.H., \& Shin, Y. (1998). Generalized impulse response analysis in linear multivariate models. Economics Letters, 58(1), 17-29.

Pesaran, M.H., Shin, Y., \& Smith, R. (2001). Bounds testing approaches to the analysis of level relationships. Journal of Applied Econometrics, 16(3), 289-326.

Phillips, P.C.B., \& Perron, P. (1988). Testing for a unit root in time series regression. Biometrika, 75(2), 335-346.

Piazolo, D. (1995). Trade integration between Eastern and Western Europe: Policies follow the market. Journal of Economic Integration, 12(3), 259-297.

Potiowsky, T., \& Qayum, A. (1992). Effect of domestic capital formation and foreign assistance on rate of economic growth. Economia Internazionale/International Economics, 45(2), 223-228.

Saptutyningsih, E., \& Suryanto S. (2011). Hedonic price approach of flood effect on agricultural land. Economic Journal of Emerging Markets, 3(1), 87-96.

Sarel, M. (1995). Nonlinear effects of inflation on economic growth (IMF Working Paper 411). Washington DC: International Monetary Fund.

Schumpeter, J.A. (1934). The theory of economic development. Cambridge, MA: Harvard University Press.

Shaari, M.S.M., Karim, M.Z.A., \& Hasan-Basri, B. (2016a). Flood disaster and GDP growth in Malaysia. European Journal of Business and Social Sciences, 4(10), 27-40.

Shaari, M.S.M., Karim, M.Z.A., \& Hasan-Basri, B. (2016b). Flood disaster and mining sector GDP growth: The case of Malaysia. International Journal of Management Sciences, 6(11), 544-553.

Shafie, A. (2009). Extreme flood event: A case study on floods of 2006 and 2007 in Johor, Malaysia. Ecological Economics, 68(4), 211-231.

Shultz, S.D., \& Fridgen, P.M. (2001). Floodplains and housing values: Implications for flood mitigation projects. Journal of the American Water Resources Association, 37(3), 595-603.

Shrestha, M.B., \& Chowdhury, K. (2005). ARDL modelling approach to testing the financial liberalization hypothesis (Working Paper 05-15, Department of Economics, University of Wollongong). Australia: University of Wollongong.

Smith, A. (1776). An Inquiry into the nature and causes of the wealth of nations. Oxford: Oxford University Press (1976).

Soentato, R., \& Proverbs, D.G. (2004). Impact of flood characteristics on damage caused to UK domestic properties: The perception of surveyors. Structural Survey, 22(2), 95-104.

Sweidan, O.D. (2004). Does inflation harm economic growth in Jordan? An econometric analysis for the period 1970-2000. International Journal of Applied Econometrics and Quantitative Studies, 1(2), 41-66.

Tang, T.C., \& Nair, M. (2002). A cointegration analysis of Malaysian import demand function: Reassessment from the bounds test. Applied Economics Letters, 9(5), 293-296. 


\section{Appendices}

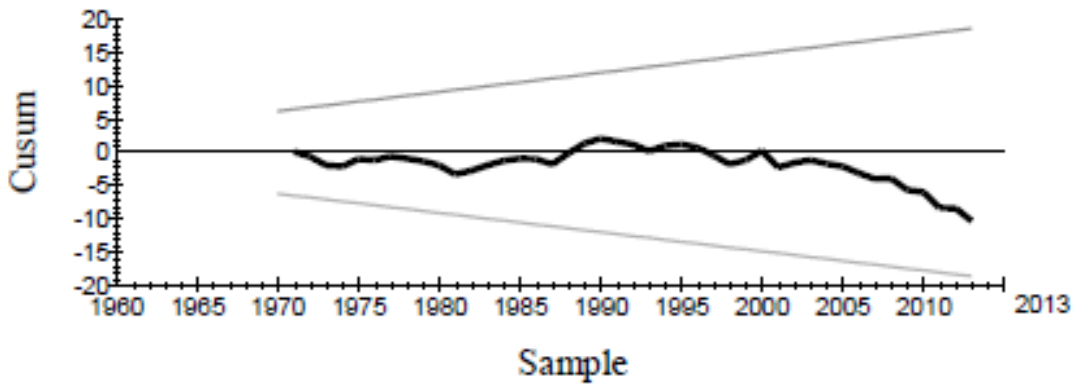

Appendix 1. Plot of cumulative sum of recursive residuals (CUSUM) for manufacturing sector. Note: The straight lines represent critical bounds at five percent significance level.

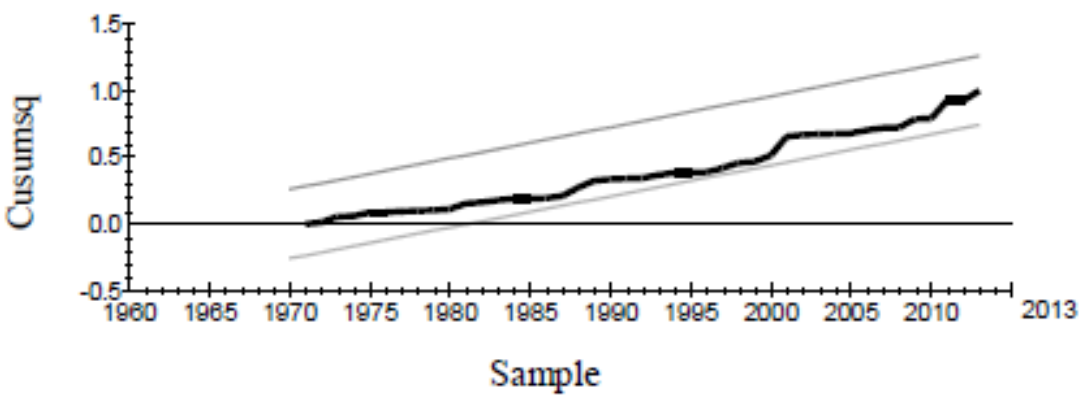

Appendix 2. Plot of cumulative sum of squares of recursive residuals (CUSUMsq) for manufacturing sector.

Note: The straight lines represent critical bounds at five percent significance level.

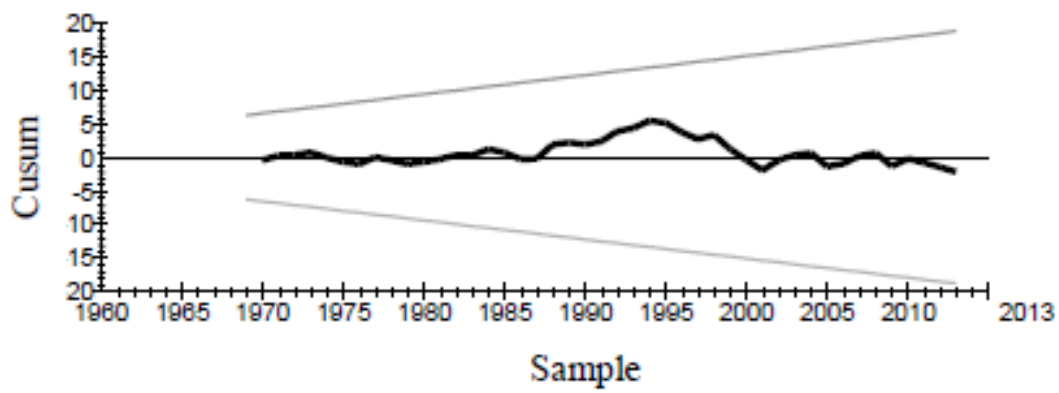

Appendix 3. Plot of cumulative sum of recursive residuals (CUSUM) for agricultural sector Note: The straight lines represent critical bounds at five percent significance level. 


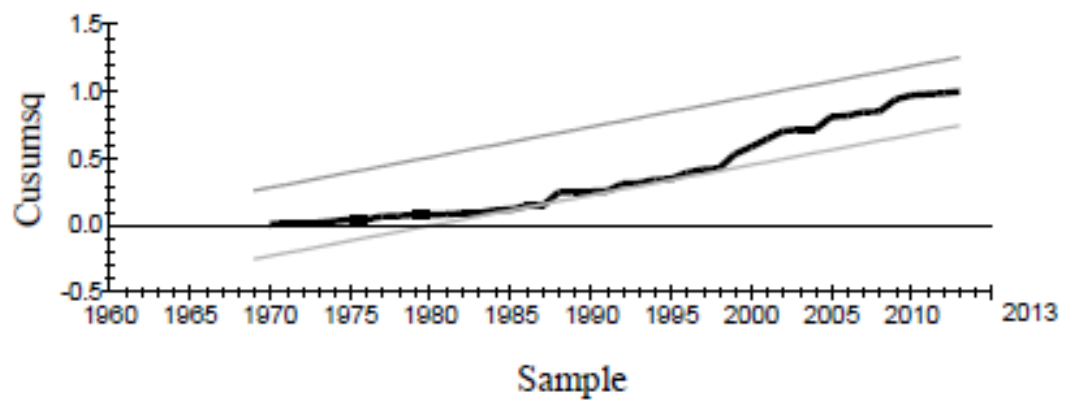

Appendix 4. Plot of cumulative sum of squares of recursive residuals (CUSUMsq) for agricultural sector

Note: The straight lines represent critical bounds at five percent significance level. 
